\title{
A Semiotic Reading of the Symbols of Yoruba Traditional Marriage
}

\author{
Oluwamayowa Victoria Ogunkunle \\ Department of English and Literary Studies, Federal University Oye-Ekiti, Ekiti State, Nigeria
}

\begin{abstract}
Communication as a means of establishing social interaction is multimodal. It entails the use of the verbal and the non-verbal means of communication. This suggests that understanding messages involves unravelling the different modes involved in communication. This fact necessitates the investigation of language at different levels and as used in many contexts. Also, the fact that language is connected to the culture of its users makes language investigation in cultural practices particularly interesting. This paper seeks to do a semiotic reading of the items used in Yoruba traditional marriage. It seeks to unravel the meaning of the elements of culture in traditional marriage ceremony and unravel the meaning of the signs (objects) used in it. Halliday's meta-functions and Pierces conception of signs are used as the theoretical framework. The paper justifies the assertion that communication is multimodal and is a system of interpreting verbal and non-verbal signs.
\end{abstract}

Index Terms - multimodal, semiotic, verbal, non-verbal, marriage, signs

\section{INTRODUCTION}

The wisdom of a race lies in the way they relate with the world they live in. Most often, the language of a people reveals the richness of their heritage and tradition. The Yoruba language as an aspect of the Yoruba culture has been described as rich and condensed. The Yoruba people are seen as a group that has beautiful and vast communication skills. The usual verbal communication among the Yoruba people is embellished with such figures of speech as irony, metaphor, and so on with many instances of proverbs and idioms. Apart from the verbal aspects of the Yoruba language, it is common practice for the Yoruba people to use non - verbal means of communication such as eye movement, tapping of the feet, silence etc. It is cultural for the people to understand, decode and respond appropriately to such nonverbal messages. A person who decodes the non- verbal gestures and act accordingly is said to be well trained while a person who does otherwise is said to lack proper training. Therefore, to become a 'complete' member of the Yoruba speech community, it is expected that one understands the various codes in the Yoruba modes of communication. This is why every instance of language use provides the member of the speech community with opportunities to associate appropriate meanings with different codes.

Many communicative events in the Yoruba culture are done through these codes. Therefore, communicative events are avenues for making meaning through the creation and interpretation of signs. Chandler (2011) states that 'signs take the form of words, images, sounds, odours, flavours, acts or objects' (P. 1), therefore, items used for traditional marriage ceremony in the Yoruba culture can be regarded as signs. These signs can be seen as tools to achieve some communicative principles. Mey (2001) identifies some of these principles and particularly describes the principle of economy as 'the human propensity towards achieving maximum effect with least possible effort' (P. 180). The items used in marriage ceremony among the Yoruba people have voices. They signal the world view of the users with respect to the context in which they are used. They are also used as tools to bear the mind of the parties involved in the ceremony to one another and to the society at large. Therefore, the signs become an 'economic' way of communicating so much with so little. It is also culturally expected that the signs will be very effective in communicating the parties' intention. The items are required by the bride's family as symbols of proper request for betrothal and they are used in praying for the new couple. How do the items required communicate adequately the intention of the parties involved in the marriage, what do this symbols mean and how do they expose the ideology of the Yoruba people about marriage? These are the concerns of this paper. It is intended that this paper will reveal the Yoruba's conception of marriage through the items used in traditional marriage ceremony and state precisely the function of each sign in this social event.

\section{LITERATURE REVIEW}

\section{A. Language and Social Semiotics}

As far as the human race is concern, language is a distinctive and essential tool for socialisation. Many researchers, especially in the sciences have described human as social animals. This suggests that one of the things that make humans who they are is their ability to socialise. Aristotle is quoted as saying "Man is by nature a social animal; an individual who is unsocial naturally and not accidentally is either beneath our notice or more than human" (Catt, 1962, p. 20). This is reinforced by the argument that human needs human to survive. For the scientist, man is born in the 
society, lives in the society and dies in the society. While linguists assert this, they however stress language as an essential tool for socialisation. To relate with human beings and establish relationships, one will need to communicate and the only means of communication is the use of language either verbal or none verbal. Halliday is a proponent of the study of language as social semiotic. According to Halliday (1978),

language is the main channel through which the patterns of living are transmitted to him (a child) through which he learns to act as members of a society in and through the various social groups, the family, the neighbourhood and so onand to adopt its culture, its mode of thought and action, its believes and values. (P. 13)

This establishes the fact that language performs a number of functions in the human society. Apart from being an instrument of socialisation, it interprets our experiences and participation in social events. Also language becomes social because it is used in social contexts thereby performing social functions. To interpret language use, language has to be situated in particular contexts. When this is done, language becomes a system of meaning. Everything employed in communicative events can be said to have a voice which it lends to the interpretation of the social events. Halliday (1978) says that 'the context plays a part in what we say and what we say plays a part in determining the context' (P. 3). Since language can be verbal and non- verbal and both can be employed in social events for meaning making, language becomes a system of social signs. It is a system because it is a network of social signs which are harnessed to make meaning. If language is a system of social signs, and the study of signs is semiotics, language can be regarded as social semiotics. This is drawn from the social interpretation of language propounded by M.A.K Halliday.

The social interpretation of language entails unravelling the meaning of language, as used in social situations, and stating its functions. Van Leeuwen (2005) describes all elements of communication (verbal and non-verbal) as semiotic resources. He referred to them as

the actions and artefacts we use to communicate, whether they are produced physiologically - with our vocal apparatus; with the muscles we use to create facial expressions and gestures, etc. - or by means of technologies - with pen, ink and paper; with computer hardware and software; with fabrics, scissors and sewing machines, etc. (P. 3)

Since all elements of communication are social resources, they can as well be termed as input for language interpretation. He also states that

social semiotics resources are signifiers, observable actions and objects that have been drawn into the domain of social communication and that have a theoretical semiotic potential constituted by all their past uses and all their potential uses and an actual semiotic potential constituted by those past uses that are known to and considered relevant by the users of the resource, and by such potential uses as might be uncovered by the users on the basis of their specific needs and interests. (P. 4)

The quotation above suggests every input communication involves the use of signs which are signifiers. This establishes the fact that the interpretation of language is a semiotic process i.e. interpretation of signs. Also, it is established that signifiers are observable in every communicative event. People employ specific mode of communication because of the noticeable effectiveness and acceptability of such strategies in the particular discursive event.

It is also clear that from Van Leeuwen (2005)

Studying the semiotic potential of a given semiotic resource is studying how that resource has been, is, and can be used for purposes of communication, it is drawing up an inventory of past and present and maybe also future resources and their uses (P. 5).

Bezemer and Kress (2008), describe signs as 'elements in which meaning and form have been brought together in a relation motivated by the interest of the sign maker' (170). This further reinforces the fact that every element of language is a sign whether, letters or symbols. The concern of this paper is to decode the voice(s) of signs, a form of non-verbal, language, as used in the traditional marriage ceremony of the Yoruba people in Oyo State.

\section{B. Signs and Semiotics.}

Communication is an integral part of human life. Every activity of man on earth can be said to communicate one message or the other. This ranges from the usual verbal communication to non -verbal communication such as gestures, looks and dispositions, sign languages such as symbols, icons and indexes etc. to communicate. As far as Hawkes (2003) is concerned, "Man's role in the world is quintessentially one of communication (P.102). He is, as Greimas argues, a receiver and sender of messages: he gathers and disseminates information". This suggests that man's activities in the world are built around communication. Human beings attempt to make meaning of their existence by communicating with themselves and to the world around them through verbal and non-verbal means. The fact that human beings communicate by non -verbal means is reinforced by Hawkes, (2003) argument that:

Language clearly plays a commanding role and is generally taken to be the predominant means of communication. But it is also clear that human beings communicate by non-verbal means and in ways which must consequently be said to be either non-linguistic... (P. 101).

The interpretation of signs as used in non- verbal communication is the concern of semiotics. According to Cobley and Jansz (1999), "the word semiotics comes from the Greek root, seme, as in semiotikos, meaning an interpreter of signs". Also, they define semiotics as a discipline concerned simply with the analysis of signs or the study of the functioning of sign systems" (P. 4). This description establishes semiotics as a field where messages through signs can be interpreted. For Julia Kristeva semiotics interprets social practices as signifiers. This means that every social event 
stands for something and as such is capable of encoding messages. Berger (2010), states that "one of the most important things that semioticians do is to decode various aspects of a culture whether it be signs found in advertisements, rituals, food practices or fashion" (P. 25). It is clear from this quotation that semioticians concern themselves with the interpretation of signs in accordance with the meaning associated with them in each culture.

Signs are defined as the "unity of word-object known as signifier with a corresponding culturally prescribed content or meaning known as a signified" (Berger, 2010, P.3). Hawkes (2003) quotes Pierces conception of sign thus, a sign or representamen is 'something which stands to somebody for something in some respect or capacity' ... it is 'anything which determines something else (it's interpretant) to refer to an object to which itself refers (its object)' (P.103). From this quotation, it can be said that anything that depicts something else can be called a sign. If a look suggests a warning, it becomes a sign, and if an object is used to communicate a particular message, the object is also a sign which is also referred to as representamen. Apart from standing for something, Hawkes also explains that it can stand for something to somebody. So, the person to whom the object stands for something is the interpretant. Also, he avers that signs can only stand for something to someone in some respects and this he referred to as the ground. According to him, the relationship between the representamen, the interpretant and the ground determines the precise nature of the process of semiosis.

Van Leeuwen (2005) says that 'semiotic resources are not limited to writing and picture making but as almost everything we do’ (P.4). For him social events can articulate different social and cultural meanings. His assertion is reinforced by Danesi (2004)'s view that “a sign is anything- a colour, a gesture, a wink, an object, a mathematical equation, etc. that stands for something other than itself". He further establishes that a semiotician's work is to focus on the concepts the signs elicit while attempting to unravel what it entails culturally and personally. (P. 6).

For Hall (2007), signs are everywhere... they are formed through the society that creates them, by the structures they employ and through the sources they use. Also for him, signs are always produced and consumed in the context of a specific society (P. 1). This idea is connected with Hawkes (2003) concept- ground. This refers to the social condition that necessitates the particular interpretation associated with the sign.

In line with Pierces classification of signs, Hall, (2007) states that icon, index and symbols are the basic building blocks for meaning-making. Also, he reinforces the idea that signs are comprises two inseparable elements which are the signifier and the signified whose relationship is said to be arbitrary. Therefore, the interpretation of signs is based on the generally acceptable association of the signifier and the signified. Danesi (2004), expresses the association between the signifier and the signified thus:

The brain's capacity to produce and understand signs is called semiosis, while the knowledge-making activity this capacity allows all human beings to carry out is known as representation. The latter can be defined more precisely as the use of signs (pictures, sounds, etc.) to relate, depict, portray, or reproduce something perceived, sensed, imagined, or felt in some physical form (P.16).

The assertion above establishes the fact that there is a cognitive aspect of sign interpretation and this involves associating signs with meaning. This is essentially dependent on the acceptable mode of interpretation across cultures.

\section{Social Semiotics and Culture.}

There is a specific kind of connection between semiotics and culture. Since semiotics deals with signs and it has been established that anything can be referred to as signs, it means that our understanding of the world is in a way semiotic. The natural world and the world we create for ourselves are filled with different signs ranging from nature to social activities humans engage in. These 'worlds' of ours are interpreted based on the opinions we have formed or which we have come to learn over a period of time. Hence, our ways of life, values, customs etc - our culture, are products of our interpretation of the world we live in. As far as the Whorfian hypothesis is concerned language conditions our world view. The hypothesis in its strong form holds that the way people view the world is determined by the features of the language they speak. This view of the world encompasses the belief system and the culture of a people. Whorf is quoted as asserting that "language conditions our world view and that different speakers view the world along the different lines laid down by their respective languages" (Akindele and Adegbite, 1999, P. 6). The different lines laid down by languages can be interpreted as signs- verbal and non-verbal. This affirms that people use the social signs around them to determine or condition their ways of life. It can also be said that such ways of life contributes to further interpretation of the world. Such that it is plausible to say that semiotics or social semiotics and culture have a dialectical relationship. This means that the elements in such relationship are "different elements but not discrete, fully separate, elements Fairclough, (2005).

Danesi, (2004) expresses the relationship between signs on the one hand and body, mind and culture on the other hand as the "conceptual glue" that interconnects their body, their mind, and the world around them in a holistic fashion" while referring to the way children make sense of the world around them. He also asserts that Once the child discovers that "signs are effective tools for thinking, planning, and negotiating meaning with others in certain situations, he or she gains access to the knowledge domain of his or her culture" (P.17). His argument also establishes the relationship between signs- the concerns of semiotics and culture. From this argument, signs are established as important tools that give meaning to the culture of a people. He further states that our understanding of the world is thus not a direct sensory one. It is mediated by signs and, thus, by the images that they elicit within our minds space. 
From the literatures reviewed, it has been established that, meaning making in semiotics is culture bound and culture serves as a means through which signs are distributed as acceptable means of communication. Also, it is established that culture preserves signs and makes them continually relevant in communication. Elements of culture are therefore to be decoded so as discover the meanings and feelings attached to them. This will give access to heart of every culture and by so doing; one will be able to understand the people in terms of their behaviour and value system. This is the concern of this paper. It seeks to unravel the meaning of the elements of culture in traditional marriage ceremony among the Yoruba people and unravel the meaning of the signs (objects) used in it. This will enable the researcher expose the ideology of the people about marriage and their behaviour in this particular context.

\section{Methodology}

Language is seen as multimodal from social semiotics perspective and this suggests that there are many modes that can enhance the interpretation of language since they are in a way components of the language. As far as this paper is concerned, the signs will be interpreted based on the meta-functions of language as proposed by Halliday (1978) while taking into consideration Pierces' triadic nature of signs as used in the social event. Meanwhile, it is important to establish the fact that the items in the marriage ceremony are part of the modes used. Since 'a mode is a socially and culturally shaped resource for making meaning' (Bezemer and Kress, 2008, p. 171), it is safe to say that those resources are modes because they are specifically selected to communicate particular meanings in the marriage ceremony.

\section{ANALYSIS AND DisCUSSION OF FINDINGS}

\section{Interpreting cultural signs}

The traditional marriage among the Yoruba people has undergone a lot of transformation and improvement from its earliest forms where parents choose partners for their children to the modern version where children find for themselves suitable partners and inform their parents about it. Through the different stages of developments, some practices have remained unchanged. This can be traced to the fact that that those practices are seen as germane to the marriage culture. The marriage culture has legalised a lot of such practices such that the marriage ceremony is not seen as complete if they are not involved. This includes the use of items for prayers during the ceremony, investigating about the other family involved and so on. The items requested by the bride's family are important in the Yoruba society as signs of proper proposal and acceptance of the proposal. Many of them are also used for naming ceremonies. Usually, a particular quality of the items is used to pray for the child. This is also true of the Yoruba traditional marriage. Apart from the fact that those items are signs of proper request for betrothal by the groom's family, they also embody the Yoruba ideology and belief about marriage and what a family should be.

According to Pierce's theory of signs, the triadic nature of semiotics represents the three stages involved in sign representation. The first level which is termed firstness refers to the quality of a sign that makes it appropriate to be the signifier i.e. the sign vehicle. This is called the signifying element. For pierce, a sign does not signify in all respect but a particular quality or attribute of it makes it appropriate for the particular context. This is also called representamen or qualisign. In the Yoruba culture, an item is selected as a sign because of an attribute or quality it has. This is evident in the marriage items. Items such as honey, alligator pepper, and fish and so on are used to pray while drawing particularly on an aspect of the qualities of the items. According to Danessi, (2004) "the type of representamen used to portray the object also shapes the meaning" (p.17). In Yoruba marriage, the fact that a fish swims with the head is used to represent the fact that the couple will be supported by their 'head' to scale through whatever difficulty they have. The head in the Yoruba culture represents the essence of a person. Since the fish also makes headway with the head literarily, it is assumed that anyone prayed for in that manner will make a progress as the fish does. A table of the items and their interpretations is presented below based on Pierces' level of interpretation of signs. 


\begin{tabular}{|c|c|c|}
\hline Firstness & $\begin{array}{l}\text { Secondness } \\
\text { Associating signs } \\
\text { with the object of } \\
\text { sign. }\end{array}$ & $\begin{array}{l}\text { Cultural application } \\
\text { Thirdness }\end{array}$ \\
\hline $\begin{array}{l}\text { Quality of Oyin } \\
\text { ( Honey) }\end{array}$ & $\begin{array}{l}\text { 1. Pleasantness } \\
\text { 2. Acceptance }\end{array}$ & $\begin{array}{l}\text { Didun didun laaba ile oloyin, aye oko ati aya a ma dun. } \\
\text { Ai fi oyin senu ka tuto, omo araye a ma feran ati oko ati aya. } \\
\text { Translation: it is only sweetness that is seen in the house of someone with honey, the lives of the } \\
\text { husband and the wife will be sweet. } \\
\text { 2. No one puts honey in the mouth and spits, people will always love the couple. }\end{array}$ \\
\hline $\begin{array}{l}\text { Quality of } \\
\text { Aadun } \\
\text { (powdered corn } \\
\text { cake) }\end{array}$ & Sweetness & $\begin{array}{l}\text { Aaye ati oko ati aya a dun a laarinrin } \\
\text { Translation: the lives of the couple will be sweet any full of fun. }\end{array}$ \\
\hline $\begin{array}{l}\text { Quality of Ireke } \\
\text { (sugar cane) }\end{array}$ & $\begin{array}{l}\text { 1. Uniqueness } \\
\text { 2. Sweetness }\end{array}$ & $\begin{array}{l}\text { Gbigbin laa gbin ogede, lilo ni aa lo ireke, nkan won yio ma yato lawujo, aye won yoo dun bi omi } \\
\text { ireke. } \\
\text { Translation: plantains are usually planted while sugar canes are planted, their things will be different } \\
\text { (positively). Their lives will be as sweet as the liquid from sugar cane }\end{array}$ \\
\hline $\begin{array}{l}\text { Quality of } \\
\text { Ataare (alligator } \\
\text { pepper) }\end{array}$ & Fruitfulness & $\begin{array}{l}\text { Ataare kii di tire ni ai kun oke, won a finu soyun won o ni bi abiku omo. } \\
\text { Translation: Alligator pepper does not pack half seeds, they will be fruitful, and they will not have still } \\
\text { birth. }\end{array}$ \\
\hline $\begin{array}{l}\text { Quality of } \\
\text { Orogbo (bitter } \\
\text { kola) }\end{array}$ & Long life & $\begin{array}{l}\text { Orogbo ni gbo ni saye, ati oko ati aya ni a gbo, won a si to. } \\
\text { Translation: Bitter kola makes one live long on earth, the couple will live nong }\end{array}$ \\
\hline $\begin{array}{l}\text { Quality of Obi } \\
\text { (cola nut) }\end{array}$ & Repelling evil & $\begin{array}{l}\text { Obi ni bi ibi danu, ibi kan ko ni sele siwon. } \\
\text { Translation: cola nut repels evil, no evil will befall them. }\end{array}$ \\
\hline $\begin{array}{l}\text { Qualities of Oti } \\
\text { (wine) }\end{array}$ & $\begin{array}{l}\text { Continuous } \\
\text { relevance }\end{array}$ & $\begin{array}{l}\text { Oti kii ti ni awujo, won o ni ti. } \\
\text { Wine never gets obsolete, may they will not become obsolete. }\end{array}$ \\
\hline $\begin{array}{l}\text { Qualities of Iyo } \\
\text { (salt) }\end{array}$ & $\begin{array}{l}\text { 1. Indispensable } \\
\text { 2. Attracts goodness }\end{array}$ & $\begin{array}{l}\text { Lai si iyo, obe ko le dun, araye yio ma fi oun rere wa oko ati aya kiri. Bi iyo tin mu obe dun ni won o } \\
\text { ma mu awujo won dun. } \\
\text { Translation: without salt, soup cannot be sweet; people will locate the couple with good things. Just as } \\
\text { salt makes the soup sweet, they will add sweetness to their environment }\end{array}$ \\
\hline $\begin{array}{l}\text { Attribute of Eja } \\
\text { (fish) }\end{array}$ & Victorious & $\begin{array}{l}\text { Ori ni eja fin la ibu ja, ori won ko ni pada leyin won } \\
\text { The fish uses its head to swim through water; their head will not abandon them. }\end{array}$ \\
\hline $\begin{array}{l}\text { Quality of Isu } \\
\text { (yam) }\end{array}$ & Abundance & $\begin{array}{l}\text { Iyan ni ounje, oka ni oogun, airi rara lan jeko, kenu ma dile ni ti guguru, ebi oni pawon, ile won yoo } \\
\text { kun fun ounje. } \\
\text { Translation: pounded yam is food, yam flour is medicine, it is only when there is none that pap ( a } \\
\text { meal made from corn which is percuiar to the Yoruba people) is taken, popcorn is taken to keep the } \\
\text { mouth busy, their home will be filled with food. }\end{array}$ \\
\hline
\end{tabular}

According to Halliday, there are three meta-functions of language. These are: the ideational, the interpersonal and the textual meta-function.

\section{A. The Ideational Meta-function of Signs}

The ideational comprises the experiential and the logical function. Butler (1985) describes the ideational component as 'serving for the expression of content' (p.47), while Halliday and Matthiessen, (2004) describe it as the grammar resources for constructing our experiences of the world around us and inside us (P. 13). The experiential component describes the content while the logical component describes the linguistic system by the fact that it is expressed through recursive structures.

The items used in the marriage ceremony encode the view of the Yoruba people about marriage. From the table above, it can be deduced that the Yoruba people have a positive conception of marriage. The qualities of the items used are the positive ones. For example, the sweetness of honey is used to express the wish that the couple experience sweetness in the marriage. Also, since yam is seen as the main food among the Yoruba people, it is used to represent and pray for abundance for the couple. In addition to this, other items express the desire such as fruitfulness which is seen as core to a Yoruba marriage, victory, long life and so on.

When items are placed together, they become a text because they communicate together at a certain level of understanding. In a way, there is a logical relationship between the items used. A critical examination of the signifiers reveals that there is a relationship of positivity among the items. So, in terms of polarity, there is the positive as against a negative image of marriage among the Yoruba people. Together they can be referred to as a text that embodies the positive image of marriage in the heart of the Yoruba people. There is cohesion in the text. This is because there is no item that contradicts the others by suggesting a negative opinion. This explains the logical function of this items used in expressing meaning. It is also possible to interpret the language of traditional marriage among the Yoruba people in terms of transitivity. Transitivity generally deals with processes. There is the material, verbal, mental, relational and circumstantial processes. The one that is easily associable to this analysis is the attributive process which is a sub-class of relational processes. The attributive process ascribes an attribute to an entity.

The attributes of the signs used are the particular qualities associated with the signifiers and that are found useful for the joining process in marriage. A very peculiar nature of the object from which the object of sign is derived in the culture is the pronunciation. It is discovered that there is a particular rhyme between the pronunciation of some words 
and the quality of the signs. A syllable of the word which is found appropriate for the intended prayer is used. The polysemous nature of Yoruba words and syllables is drawn upon in the praying process. One is used to mean another so as to fulfil the intention of the user. For example:

Aadun (powdered corn cake), has as its last syllable 'dun' which means sweet and that is what is drawn upon in the process of praying for the couple. Also, for Orogbo (bitter kola), the last syllable which is 'gbo' (mature) is drawn upon to emphasise the prayer that the couple will live long. In addition to this, the last syllable of the words- 'Oti' (wine) 'ti' (irrelevance) and 'Obi' (colanut) - 'bi' (repel) is used to pray for the couple. These syllables in contrast to the first two are negative and so are used to emphasise that the quality will never be associated with the couple.

Other qualities of items can also be used to pray for the couple in the marriage ceremony. The function of salt among people of the world is drawn upon to pray for the couple. It is believed that salt is indispensable, and so the couples are prayed for that they will be indispensable. For yam, it is believed that it is the 'king' of food in the Yoruba setting and so it is used to pray for the couple that they will not lack food in their home. It is important to note that these items are provided by the groom's family and this signifies that the man will always provide for his home. Also, the items are not used to pray for the couple as individuals but as a unified whole. This suggests that the Yoruba sees the family as an entity that deserves goodness in all sense of it. Since the family makes up the society, they believe that a family has to be properly structured so as to build a unified and sane society. This is the reason why the society believes that the family deserves all the goodness it can get from the society.

\section{B. The Interpersonal Meta-function}

The interpersonal function describes the interaction between the participants in a conversation. It deals with the analysis of the structural relations of the clause which is concerned with the mood (Bloor and Bloor, 1995, P.29).

The mood of the items used can be said to be declarative. The objects are not used to suggest that the particular qualities used in them may be associated with the couple; they are used to declare what will happen or what the wishes of the participants are for the marriage and the couple. Since, the items are predominantly used to pray and prayers are usually declarative, it is justifiable that the mood is declarative. In some of the prayers, the declarations are modulated through the use of modal auxiliaries.

\section{The Textual Meta-function of Signs}

The textual meta-function describes the resources needed in presenting the ideational and the interpersonal metafunctions. It relates to how topics are developed and projected. It involves transition in the development of text (conjunctive relation) (Halliday and Matthiessen, 2004, P. 21). Since the data is primarily a non-verbal means of communication, it is a little difficult to analyse the thematic structure. However, the information structure can be analysed based on the given and new information. According to Bloor and Bloor (1995), "we instinctively try to organise what we say in a way that will make it easier for the hearer or reader to understand" (P.65). The hearer must be able to situate the information in a way in his own wealth of experiences. This suggests that information usually should move from the simpler to more complex even though this is not always so and the assertion cannot be prescriptive since most spoken discourse are not planned.. By implication, information should move from given to new information. In SFL language, given information refers to the shared knowledge between the participants in a social event while new information refers to the focus of the speaker's information. In the data under consideration, the given information is the shared knowledge about the qualisign i.e the particular quality of the sign that makes it appropriate to serve as the signifier. Hence, the sweetness of honey, the fact that the fish swims with the head, the fact that yam is a major food among the Yoruba and so on is given information. The new information therefore is the application of the quality to the social event in this case the marriage ceremony and particularly praying for the couple. For instance, it is given information that orogbo (bitter cola) ends with the 'gbo' syllable which can also be interpreted as mature. The new information is the application of the meaning of gbo (mature) to the life of the couple. This type of analysis goes for all the items used in the traditional marriage ceremony.

\section{CONCLUSION}

Language has been justified as social semiotics and communication as a system of interpreting signs. These signs cannot be isolated but are culture-bound in interpretation. This is reflected in the analysis of the signs in the Yoruba traditional marriage ceremony. It is also clear from this analysis that both verbal and non-verbal languages have metafunctions. Also, Chandler's assertion that anything can be a sign as long as someone interprets it as 'signifying' something - referring to or standing for something other than itself is justified in the analysis. It can be drawn from the analysis that the Yoruba traditional marriage ceremony encodes the culture of the people about marriage and therefore expresses their ideology about marriage.

\section{REFERENCES}

[1] Adewoyin S.Y. (2006). Imo Ede, Asa, ati Litireso Yoruba. Corpromutt (publishers) Nig. Limited; Lagos.

[2] Akindele, F. and Adegbite, W. (1999). The sociology and politics of English language in Nigeria: an introduction. Ile-ife: OAU press. 
[3] Berger, A. A. (2010). The Object of Affection: Semiotics and Popular Culture. Palgrave Macmillan; USA.

[4] Bezemer and Kress. (2008). Writing in Multimodal Texts: a Social Semiotic Account of Design for Learning in Written Communication. Sage publication retrieved on from http://wcx.sagepub.com/content/25/2/166 (accessed 16th January 2012).

[5] Bloor, T and Bloor, M. (1995). The Functional Analysis of English: A Hallidayan Approach. Great Britain: Arnold publishing house.

[6] Butler, C.S. (1985). Systemic linguistics: Theory and Application. London: Burtsford academic and educational imprint ob B T.

[7] Catt, G. Man the Social Animal. The Western Socialist. 29. 226, 20-21.

[8] Chandler, D. (2011). Sign: Semiotics for Beginners. http://users.aber.ac.uk/dgc/Documents/S4B/sem13.html (accessed 13th Feb. 2013).

[9] Cobley and Jansz. (1999). Introducing Semiotics. Icon books Ltd; Cambridge.

[10] Danessi. (2004). Messages, Signs and Meanings: A Basic Textbook in Semiotics and Communication Theory. Canadian Scholars Press; Toronto.

[11] Daramola O. and Adebayo J. (1975). Asa ati Orisa Ile Yoruba. Oniboje Press: Ibadan

[12] Eggins, S. (1994). An Introduction to Systemic Functional Linguistics. London: Pinter.

[13] Fairclough, N. (2005) Peripheral Version: Discourse Analysis in Organisational Studies: the Case of Critical Realism. http://oss.sagepub.com/cgi/content/abstract/26/6/915 (accessed 21st Jan. 2011).

[14] Hall, S. (2007). This Means This, This Means That. Lawrence King Publishing Ltd; London.

[15] Halliday, M.A K. and Matthiessen, C. (2004). An Introduction to Functional Grammar. London: Arnold.

[16] Halliday, M.A.K and Hassan, R. (1989). Language, Context and Text: Aspects of Language in a Social Semiotic Perspective. 2nd edition. New York: Oxford University Press.

[17] Halliday, M.A.K. (1978). Language as Social Semiotic: the Social Interpretation of Language and Meaning. London: Edward Arnold.

[18] Hawkes, T. (2003). Structuralism and Semiotics. New York: Routledge.

[19] Mey J. L. (2001). Pragmatics. Blackwell Publishing: USA.

[20] Van Leeuwen, T. (2005). Introduction to Social Semiotics. Routledge: London and New York.

Oluwamayowa Victoria Ogunkunle has her First Degree and Masters in English Language from Obafemi Awolowo University, Ile-Ife, Osun State, Nigeria and University Of Ibadan, Oyo State, Nigeria respectively.

She is an ASSISTANT LECTURER in the Department of English and Literary Studies, Federal University Oye-Ekiti, Ekiti State, Nigeria. She is also a Ph.D student in the department of English, University of Ibadan, Oyo state, Nigeria. She presently teaches English Composition and English Phonetics in the department. Her research interest includes Critical Discourse Analysis, Multimodal Discourse Analysis, Social Semiotics and Cultural Studies. 